ROCZNIKI NAUK PRAWNYCH

Tom XXIX, numer $1-2019$

DOI: http://dx.doi.org/10.18290/rnp.2019.29.1-6

ROBERT ZIELIŃSKI

\title{
FUNKCJE PODATKÓW W DOKTRYNIE PRAWNOFINANSOWEJ ORAZ ICH ZNACZENIE DLA PRAKTYKI STANOWIENIA PRAWA PODATKOWEGO
}

\section{WPROWADZENIE}

W piśmiennictwie prawnofinansowym i ekonomicznym pojęcie funkcji nie jest jednolicie rozumiane. Zauważyć bowiem można, że występują w tym zakresie cztery grupy poglądów ${ }^{1}$. Po pierwsze, funkcje utożsamia się z celami i zadaniami, jakie spełniają podatki i finanse. $\mathrm{W}$ tym ujęciu funkcje identyfikowane są z: rolą jaką spełniają finanse jako zjawiska ekonomiczne, czy też z najważniejszymi zadaniami, w których wyraża się społeczna istota finansów, jak również $\mathrm{z}$ realizowanymi $\mathrm{w}$ ramach publicznej działalności finansowej celami ekonomicznymi i politycznymi, a także z zadaniami, jakie finanse spełniają $\mathrm{w}$ stosunkach społecznych i w całym systemie finansowym ${ }^{2}$. W powyższym znaczeniu funkcje zjawisk finansowych polegają na wyjaśnieniu ich roli w osiąganiu różnorodnych celów społeczno-gospodarczych ${ }^{3}$. Po drugie, łączy się je z funkcjonowaniem i są one urzeczywistniane za pośrednictwem różnych metod i narzędzi stosowanych

Dr RoBert ZiELIŃSKI - adiunkt w Zakładzie Prawa Finansowego i Podatkowego, Kolegium Prawa Akademii Leona Koźmińskiego w Warszawie, ul. Jagiellońska 59, 03-301 Warszawa; e-mail: rzielinski@kozminski.edu.pl; https://orcid.org/0000-0002-0100-1457

${ }^{1}$ E. Tegler, Funkcje systemu podatkowego i ocena jego sprawności, „Acta Universitatis Lodziensis", Folia Iuridica 54 (1992), s. 105.

${ }^{2}$ J. Harasimowicz, Finanse i prawo finansowe, Warszawa: Państwowe Wydawnictwo Ekonomiczne 1988, s. 13; L. KURowski, M. Weralski, Prawo finansowe, Warszawa: PWN 1970, s. 12; J. JaŚKIEwiCZOwa, Prawo finansowe, Gdańsk: Wydawnictwo Uniwersytetu Gdańskiego 1988, s. 12; Z. FEDOROwICZ, Finanse w gospodarce socjalistycznej, Warszawa: Państwowe Wydawnictwo Ekonomiczne 1974, s. 125, za: TEGLER, Funkcje systemu podatkowego, s. 105 oraz J. SoKOŁOwSKI, Zarzadzanie przez podatki, Warszawa: PWN 1995, s. 23.

${ }^{3}$ J. WierzBICKI, J. Wolniak, Finanse $w$ socjalizmie, Warszawa: Państwowe Wydawnictwo Ekonomiczne 1979, s. 78. 
przez różne instytucje i urządzenia systemu finansowego ${ }^{4}$. Zauważyć przy tym należy, że poszczególne instrumenty i metody gospodarki finansowej oraz polityki finansowej funkcjonują w odmienny, sobie właściwy sposób, co oznacza, że podatki pełnią różne funkcje ${ }^{5}$. Po trzecie, termin funkcje łączony jest ze skutkami poszczególnych zjawisk finansowych, w tym także podatków i systemu podatkowego, jakie system ten wywołuje ${ }^{6}$. I po czwarte, co wydaje się być najbardziej przekonywujące i najbliższe istocie omawianego zagadnienia, funkcje wywodzą się z samej istoty finansów, jako zjawiska ekonomicznego o obiektywnym charakterze, natomiast osiągane przez nie skutki zależą od stopnia umiejętności posługiwania się nimi ${ }^{7}$. Jednocześnie, w doktrynie podkreśla się, że funkcje podatków muszą być zbliżone do funkcji systemu finansowego, zaś różnice dotyczyć mogą jedynie ich zakresu ${ }^{8}$. Powyższe twierdzenie uzasadniane jest tym, że system podatkowy stanowi istotny element systemu (podsystemu) finansowego państwa, tym samym w swojej budowie musi uwzględniać wymogi zeń wynikające, a jednocześnie go kształtować ${ }^{9}$.

Celem niniejszego opracowania jest syntetyczne przedstawienie funkcji, jakie w doktrynie prawnofinansowej realizują podatki oraz wskazanie na ich znaczenie dla praktyki prawa podatkowego.

\section{KATALOG FUNKCJI PODATKÓW}

W literaturze przedmiotu brak jest ogólnego katalogu funkcji podatków, a różnice, jakie istnieją w tym względzie nie tyle dotyczą poszczególnych funkcji, co ich liczby ${ }^{10}$. Jednocześnie podkreśla się, że funkcje te nie tworzą zamkniętego katalogu, a szczegółowe ich zestawy opierają się na cechach, które uważa się za

\footnotetext{
${ }^{4}$ A. Komar, W. ŁączKowSKI, Finanse i prawo finansowe, Warszawa: PWN 1976, s. 101, za: TEGLER, Funkcje systemu podatkowego, s. 106.

${ }^{5}$ S. Bolland, Wstęp do nauki finansów, Warszawa: Państwowe Wydawnictwo Ekonomiczne 1986, s. 13, za: TEGLER, Funkcje systemu podatkowego, s. 106.

${ }^{6}$ E. CZERwiŃSKA, Niektóre sporne problemy $w$ dyskusji o finansach, [w:] Istota i funkcje finansów socjalistycznych. Zagadnienia dyskusyjne, red. B. Blass, Z. Fedorowicz, M. Orłowski, Warszawa: Państwowe Wydawnictwo Ekonomiczne 1965, s. 63 n., za: TEGLER, Funkcje systemu podatkowego, s. 106.

${ }^{7}$ Tamże, s. 107; A. Majchrzycka-Guzowska, Finanse i prawo finansowe, Warszawa: Wydawnictwo Prawnicze PWN 1995, s. 77.

${ }^{8}$ KOMAR, ŁĄCZKOWSKI, Finanse i prawo finansowe, s. 101.

${ }^{9}$ S. Dolata, Podstawy wiedzy o podatkach i polskim systemie podatkowym, Opole: Wydawnictwo Uniwersytetu Opolskiego 1999, s. 54.

${ }^{10}$ J. GŁuChOwsKI, Funkcje podatków w gospodarce rynkowej, „Przegląd Ustawodawstwa Gospodarczego" 5 (1995), s. 2.
} 
najważniejsze, zaś zakres ich oddziaływania jest tym szerszy, im większy jest zasięg samych podatków ${ }^{11}$. Wynika to m.in. $\mathrm{z}$ faktu, że funkcje systemu podatkowego ulegały swoistej ewolucji nierozerwalnie związanej $\mathrm{z}$ przeobrażeniami społeczno-gospodarczymi i polityczno-ustrojowymi, jakie miały miejsce w poszczególnych państwach. Jak wskazuje się w literaturze przedmiotu, początkowo bardzo ostrożnie, ale w miarę upływu czasu coraz bardziej i wyraźniej podatki zaczęły przechodzić od spełniania wyłącznie funkcji podstawowych, takich jak ochrona i bezpieczeństwo, ład i porządek w państwie, do prowadzenia aktywnej polityki na polu gospodarczym i społecznym, w wyniku czego zaczęto je wykorzystywać jako narzędzia osiągania celów gospodarczych oraz społecznych ${ }^{12}$. Stąd też, w piśmiennictwie prawnofinansowym w katalogu funkcji, jakie realizują podatki powszechnie wymienia się funkcję fiskalną oraz funkcje pozafiskalne ${ }^{13}$. Podkreśla się przy tym, że funkcja fiskalna może być odnoszona zarówno do pojedynczego podatku, jak i do ogółu podatków składających się na system podatkowy, natomiast funkcje pozafiskalne wyrażają się w wykorzystywaniu ich dla potrzeb oddziaływania przez państwo na życie gospodarcze i społeczne ${ }^{14}$. Zwraca się także uwagę, że miarą prawidłowej konstrukcji podatku jest zdolność do pełnienia przezeń zarówno funkcji fiskalnej, jak i istotnych funkcji pozafiskalnych ${ }^{15}$.

\section{FISKALNA FUNKCJA PODATKÓW}

Funkcja fiskalna uważana jest zarówno w doktrynie prawa finansowego, jak i w ekonomii za podstawową oraz najstarszą funkcję, jaką spełniają podatki ${ }^{16}$.

\footnotetext{
${ }^{11}$ Tamże.

12 A. GomuŁowicZ, Funkcje systemu podatkowego, [w:] A. GomUŁowiCZ, D. MĄCZYŃSKI, Podatki i prawo podatkowe, Warszawa: Wolters Kluwer 2016, s. 349.

${ }^{13}$ Niekiedy zamiast określenia „funkcja fiskalna” używa się zwrotów „funkcja dochodowa”, „funkcja skarbowa”, ,funkcja akumulacyjna” lub „funkcja alimentacyjna”.

${ }^{14}$ S. WiCIAK, Funkcja podatków w gospodarce rynkowej - analiza krytyczna, „Zeszyty Naukowe Wydziału Zamiejscowego w Chorzowie Szkoły Wyższej Bankowej w Poznaniu” 14 (2012), s. 64.

${ }^{15}$ A. Borodo, Polskie prawo finansowe. Zarys ogólny, Torun: TNOiK 2003, s. 95.

${ }^{16}$ Tak m.in.: B. BRZEZIŃSKI, Wstęp do nauki prawa podatkowego, Toruń: TNOiK 2001, s. 67; GŁuChOwski, Funkcje podatków, s. 3; MAJChrZYCKA-GuzowsKA, Finanse i prawo finansowe, s. 77; SoKoŁowsKi, Zarzadzanie przez podatki, s. 23; L. ETEL, System podatkowy (zarys wyktadu), Siedlce: Wyższa Szkoła Finansów i Zarządzania w Siedlcach 2002, s. 27; P.M. GAudemET, J. Molinier, Finanse publiczne, Warszawa: Polskie Wydawnictwo Ekonomiczne 2000, s. 422; R. DZIEMianowicz, R. PrZYGODZKa, Funkcje podatków i ocena ich sprawności $w$ rolnictwie, [w:] Kierunki reformy polskiego systemu podatkowego, red. A. Pomorska, Lublin: Wydawnictwo Uniwersytetu Marii Curie-Skłodowskiej 2003, s. 434; K. NizıoŁ, Prawne aspekty polityki podatkowej,
} 
W przeszłości, a zwłaszcza w ekonomii klasycznej, wyrażano nawet pogląd, że jest to jedyna ich funkcja. Jak twierdził R. Rybarski: ,podatek jest instytucją skarbową, ma przede wszystkim przynosić dochód, może mieć uboczne cele, gdy jednak formy podatku używa się dla osiągania jakiegoś celu pozafiskalnego, wówczas mamy do czynienia z podatkiem pozornym [...] zostaje tylko forma podatku, a zanika jego charakter" ${ }^{\prime 17}$. Podobne poglądy głosił R. Stourm, wskazując że ,podatek nie powinien być ani stymulatorem, ani moralizatorem, ani też protektorem, lecz wyłącznie zaopatrzeniem Skarbu" ${ }^{\prime 18}$.

Fiskalny cel podatków, jako ich cel podstawowy, znajduje uzasadnienie przede wszystkim w tym, że podatki stanowią podstawowe źródło dochodów związku publicznoprawnego (państwa lub jednostki samorządu terytorialnego) i tym samym umożliwiają realizację jego celów społeczno-gospodarczych, służąc pokryciu wydatków publicznych ${ }^{19}$. Jak stwierdza się w fachowym piśmiennictwie, pomimo, że państwo może realizować te cele za pomocą innych instrumentów finansowych (np. kredytów) oraz metod administracyjnych, to jednak nie ma możliwości zapewnienia finansowania wydatków publicznych innymi środkami, niż podatki ${ }^{20}$. Należy przy tym mieć na uwadze, że wykorzystanie podatków dla realizacji celów innych niż fiskalne może prowadzić do nadmiernego skomplikowania systemu podatkowego, naruszać jego stabilność, zmniejszać wydajność, a w konsekwencji sprawić, że pobór podatków stanie się trudniejszy i bardziej kosztowny, zaś możliwości uchylania się od opodatkowania większe. Mając to na uwadze wskazuje się, że posługiwanie się systemem podatkowym dla innych celów niż fiskalne powinno być ograniczone jedynie do nielicznych i szczególnie wskazanych przypadków, kiedy inne metody nie znajdują zastosowania ${ }^{21}$. Jak twierdził M. Lauré: trudno jest wywrzeć bezpośredni wpływ na gospodarkę używając systemu podatkowego, gdyż podatki są instrumentem pobierania dochodów, nie zaś ich kierowania. System podatkowy to chirurgia, tyle że nie ciała, lecz portfela (co jest nawet jeszcze gorsze). Lancetem się nie kieruje, lancetem się tnie $^{22}$.

Warszawa: Difin 2007, s. 67; A. KRAJEwskA, Podatki w Unii Europejskiej, Warszawa: Polskie Wydawnictwo Ekonomiczne 2012, s. 57.

${ }^{17}$ R. RYBARSKI, Nauka skarbowości, Warszawa: Zakład Drukarski F. Wyszyński i S-ka 1935, s. 18.

${ }^{18}$ MAJCHRZYCKA-GuZOWSKA, Finanse i prawo finansowe, s. 78.

${ }^{19}$ Krajewska, Podatki w Unii Europejskiej, s. 57-58; Gaudemet, Molinier, Finanse publiczne, s. 428-429.

${ }^{20}$ Tamże.

${ }^{21}$ Tamże.

${ }^{22}$ M. LAURÉ, Traité de politique fiscale, Paris: Presses Universitaires de France 1956, s. 112, za: Gaudemet, Molinier, Finanse publiczne, s. 423. 
Z powyższego twierdzenia nie należy jednak wywodzić wniosku, że względy sprawiedliwości społecznej nie powinny być w ogóle brane pod uwagę przy konstruowaniu podatków. Uzasadnieniem podatku jest rozłożenie obciążeń publicznych stosownie do zdolności podatkowej obywateli, przy ocenie której należy brać pod uwagę przesłanki społeczne ${ }^{23}$.

Istota funkcji fiskalnej sprowadza się do tego, że podatki pełnią bardzo ważną rolę stanowiąc podstawowy rodzaj dochodów budżetowych ${ }^{24}$. Realizacja tej funkcji polega zatem na zapewnieniu odpowiedniej wysokości dochodów budżetowych niezbędnych do sfinansowania wydatków publicznych. $\mathrm{Z}$ powyższego wynika, że funkcja fiskalna podatków ma powszechny charakter i jest realizowana przez każdy podatek, a jej znaczenie, jak podkreśla się w literaturze przedmiotu, rośnie wraz z rozwojem gospodarczym państw ${ }^{25}$. Inaczej mówiąc, podatek stanowiąc dochód związku publicznoprawnego (państwa bądź jednostki samorządu terytorialnego) pełni tę funkcję niejako automatycznie ${ }^{26}$. Warto także pamiętać, że w różnych okresach historycznych i odmiennych warunkach politycznych, społecznych i gospodarczych funkcja fiskalna podatków nie była realizowana w jednakowy sposób, zaś po II wojnie światowej w państwach tzw. obozu socjalistycznego podejmowano nawet próby jej ograniczania na rzecz innych funkcji podatku, a nawet dążono do jej wyeliminowania ${ }^{27}$. Jednakże, co należy wyraźnie podkreślić, nie wszystkie podatki realizują tę funkcję w takim samym stopniu ${ }^{28}$. I tak, podatkom pośrednim przypisuje się niekiedy wyłącznie cele fiskalne ze względu na ich wydajność i prostotę poboru ${ }^{29}$. Natomiast podatki bezpośrednie, w szczególności podatek obciążający dochody osobiste obywateli, uważa się za predestynowany do pełnienia roli łagodzenia rozwarstwienia dochodowego poszczególnych grup społeczeństwa ze względu na jego powszechny i osobisty charakter, obciążający dochody globalne podatników ${ }^{30}$. Warto również zwrócić uwagę na to, że funkcja fiskalna podatków nie polega jedynie na prostej maksy-

\footnotetext{
${ }^{23}$ GAUdEMET, Molinier, Finanse publiczne, s. 429.

${ }^{24}$ J. GŁUCHOWSKI, Polskie prawo podatkowe, Warszawa: Wydawnictwo Naukowe PWN 1993, s. 10.

${ }^{25}$ Por. R. WolaŃSKI, System podatkowy w Polsce, Warszawa: Wolters Kluwer 2016, s. 29.

${ }^{26}$ HaRAsimowicz, Finanse i prawo finansowe, s. 119.

${ }^{27}$ W. Wójtowicz, Pojęcie i charakter podatku jako dochodu publicznego, [w:] Prawo podatkowe - część ogólna i szczegótowa, red. W. Wójtowicz, Bydgoszcz-Lublin: Oficyna Wydawnicza Branta 2005, s. 40.

${ }^{28}$ NiziOE, Prawne aspekty polityki podatkowej, s. 67.

${ }^{29}$ H. KuZińsKA, Rola podatków pośrednich w Polsce, Warszawa: Wydawnictwo Wyższej Szkoły Przedsiębiorczości i Zarządzania 2002, s. 32.

${ }^{30}$ A. POMORSKA, Potrzeba wzmocnienia funkcji redystrybucyjnej podatku dochodowego od osób fizycznych, [w:] Potrzeba i kierunki reformy podatków dochodowych w Polsce, red. A. Pomorska, Lublin: Wydawnictwo KUL 2016, s. 55.
} 
malizacji wpływów podatkowych, ale rozpatrywana jest raczej w aspekcie tzw. efektywności fiskalnej, uwzględniającej nie tylko pożądany zakres sfinansowania wydatków publicznych dochodami podatkowymi (tj. wydajność fiskalną), ale także tzw. „,koszty opodatkowania” tym podatkiem, do których zalicza się zarówno koszty poboru (koszty administracyjne), koszty dostosowania podatników do przepisów podatkowych, a także koszty substytucji (efektywności) wynikające ze zniekształcającego wpływu podatków na decyzje gospodarcze, jak również na rynek pracy ${ }^{31}$.

Jak podkreśla się w piśmiennictwie prawnofinansowym, mimo że podstawowym celem podatku powinien być cel fiskalny, to jednak nie powinien on powodować ubocznych, negatywnych skutków w sferze gospodarczej czy społecznej ${ }^{32}$. Oznacza to, że podatki nie powinny cechować się nadmiernym fiskalizmem ${ }^{33}$. Ma on miejsce wówczas, gdy podatki pobierane są w nieadekwatny sposób w odniesieniu do zdolności płatniczej podatników, bądź też wysokość pobieranych podatków nie znajduje uzasadnienia prawnego ${ }^{34}$.

\section{POZAFISKALNE CELE OPODATKOWANIA}

Priorytet celu fiskalnego nie przesądza również o tym, że jest to jedyny ich cel. Współcześnie bowiem podatkom przypisuje się pełnienie różnorodnych funkcji pozafiskalnych ${ }^{35}$ umożliwiających realizację zadań o charakterze gospodarczym, społecznym, a nawet politycznym ${ }^{36}$.

W doktrynie prawa finansowego wśród pozafiskalnych funkcji podatków najczęściej wymienia się ich funkcję redystrybucyjną (określaną także jako rozdzielcza, regulacyjna, dystrybucyjna, wyrównawcza), stymulacyjną oraz informacyjnokontrolną, podkreślając jedocześnie, że ich realizacja możliwa jest jedynie wtedy,

\footnotetext{
${ }^{31}$ E. MAŁECKA-ZIEMBIŃSKA, Efektywność fiskalna podatku dochodowego od osób fizycznych w Polsce, Poznań: Wydawnictwo UE w Poznaniu 2012, s. 54.

${ }^{32}$ NizioŁ, Prawne aspekty polityki podatkowej, s. 68.

${ }^{33}$ Rozpatrując poziom obciążeń fiskalnych warto mieć na uwadze, że zjawisko fiskalizmu determinowane jest nie tylko wysokością świadczeń podatkowych, ale również innymi (parapodatkowymi) daninami publicznymi, jak np. wysokość składek na powszechne ubezpieczenie społeczne i zdrowotne.

${ }^{34}$ A. GomuŁowicz, Mentalność i moralność podatkowa, „Glosa” 3 (1995), s. 2.

${ }^{35} \mathrm{Na}$ pozafiskalne cele podatków jako pierwszy zwrócił uwagę A. Wagner. Następnie, w XX w. pod wpływem teorii J.M. Keynesa pozafiskalne aspekty podatków zaczęły nabierać dużego znaczenia.

${ }^{36}$ Dziemianowicz, PrZYGodzKa, Funkcje podatków, s. 434. W literaturze spotkać można się również z poglądami, że cele społeczno-gospodarcze są ważniejsze niż cele fiskalne; por. L. PARUSIŃSKI, Krytyczna analiza podatków pośrednich w Polsce, ,Transformacja Gospodarki” 56 (1995), s. 42.
} 
gdy prawidłowo spełniana jest funkcja fiskalna podatków ${ }^{37}$. Jedynie wówczas, gdy możliwe jest zgromadzenie wystarczających zasobów finansowych, dzięki czemu realne staje się ich dzielenie oraz przemieszczanie do innych obszarów działalności, jak również możliwe jest rezygnowanie $\mathrm{z}$ pewnych obciążeń podatkowych tam, gdzie ewentualnie pobranie podatku może prowadzić do zniszczenia jego źródła ${ }^{38}$.

W literaturze przedmiotu wyrażany jest pogląd, że funkcja dochodowa i regulacyjna stanowią dwa aspekty ogólniejszej redystrybucyjnej funkcji finansów ${ }^{39}$. Wobec tego funkcję redystrybucyjną, podobnie jak fiskalną uważa się za podstawową funkcję podatków, niezależnie od tego, w jakich warunkach społecznoustrojowych podatki są pobierane ${ }^{40}$. Wskazuje się ponadto, że funkcja ta jest „obiektywnie konieczna”, ponieważ „rozkład źródeł dochodów nie pokrywa się $\mathrm{z}$ rozkładem potrzeb finansowania" ${ }^{41}$. Nie ulega wątpliwości, że poprzez odpowiednio skonstruowany system podatkowy państwo może kierować procesem redystrybucji produktu społecznego (produktu krajowego brutto), a w pewnym stopniu także uczestniczyć w takim procesie ${ }^{42}$. Część dochodów w postaci podatków jest bowiem przesuwana od podmiotów gospodarczych i ludności do budżetu państwa, gdzie służy realizacji funkcji państwa, czyli zadań społecznych, oświatowych, zdrowotnych, obronnych itp. ${ }^{43}$ Podatki pozwalają jednocześnie regulować udział w dochodzie narodowym tych podmiotów, w stosunku do których państwo nie może posługiwać się innymi instrumentami, takimi jak ceny czy płace ${ }^{44}$. Dzięki odpowiedniemu ukształtowaniu elementów technicznych konkretnego podatku (w szczególności zastosowaniu odpowiedniej skali podatkowej, wysokości stawek podatkowych, ulg, zwolnień i wyłączeń podatkowych, kwot wolnych od opodatkowania oraz warunków i terminów płatności podatku) łagodzi i koryguje nierówności w dochodach podatników ograniczając siłę nabywczą najzamożniejszych i jednocześnie zwiększając siłę nabywczą osiągających najniższe dochody ${ }^{45}$.

\footnotetext{
${ }^{37}$ Z. OfIARSKI, Ewolucja funkcji pozafiskalnej podatków w Polsce po roku 1990, [w:] Kierunki reformy, s. 101.

${ }^{38}$ Tamże, s. 101-102.

${ }^{39}$ HARASIMOWICZ, Finanse i prawo finansowe, s. 120.

${ }^{40}$ M. WeRALSKI, Funkcje podatków a instrumenty podatkowe, [w:] System instytucji prawnofinansowych PRL, t. III: Instytucje budżetowe, red. M. Weralski, Warszawa: Ossolineum 1985, s. 56 oraz Tegoż: Zagadnienia systemu podatkowego w państwach socjalistycznych, Warszawa: Państwowe Wydawnictwo Ekonomiczne 1965, s. 30; TEGLER, Funkcje systemu podatkowego, s. 110.

${ }^{41}$ E. MAŁECKA-ZIEMBiŃSKA, Podatek dochodowy jako regulator dochodów osób fizycznych w Polsce okresu transformacji ustrojowej, Poznań: Wydawnictwo Akademii Ekonomicznej w Poznaniu 2006, s. 13.

${ }^{42}$ WóJTOwiCz, Pojęcie i charakter podatku, s. 42.

${ }^{43}$ WolańsKi, System podatkowy w Polsce, s. 30.

${ }^{44}$ GŁUChOwsKi, Funkcje podatków, s. 4.

${ }^{45}$ Dziemianowicz, PrZygodzKa, Funkcje podatków, s. 436.
} 
Należy jednak pamiętać, że zakres redystrybucji podatkowej determinowany jest strukturą danej gospodarki (jest on szerszy w tych państwach, w których występuje wiele sektorów gospodarki: państwowy, spółdzielczy, drobnotowarowy i kapitalistyczny $)^{46}$, jak też stopniem centralizacji i koncentracji gospodarki, co z kolei związane jest z zakresem i celami wydatków budżetowych ${ }^{47}$.

W literaturze przedmiotu zwraca się ponadto uwagę, że redystrybucyjna funkcja podatków może być realizowana zarówno poprzez różne formy bezpośredniego, jak i pośredniego opodatkowania ${ }^{48}$. Jednakże podkreśla się, że funkcję tę realizują przede wszystkim podatki nieprzerzucalne lub trudno przerzucalne, do których zalicza się podatki dochodowe ${ }^{49}$, a w szczególności podatek od dochodów osobistych. Stanowiąc powszechną pod względem podmiotowym i przedmiotowym daninę o charakterze bezpośrednim obciążającą w ostateczny sposób dochód podatnika w fazie jego powstawania, winien być nakładany stosownie do zdolności podatkowej, a więc zależnie od osobistej sytuacji podatnika, rodzaju przedmiotu i jego ilościowego ujęcia ${ }^{50}$. Przyjęcie powyższego założenia powoduje, że realizacja redystrybucyjnej funkcji podatków rodzi określone, praktyczne kontrowersje $^{51}$. Z jednej strony, polegają one na wskazaniu granicy, do jakiej istniejące w społeczeństwie nierówności dochodów są korzystne dla gospodarki, a z drugiej - od jakiej zaczynają się negatywne konsekwencje wpływu tych nierówności na procesy gospodarcze oraz sytuację społeczną i polityczną kraju ${ }^{52}$. Ponadto pewne trudności dotyczą także doboru instrumentów umożliwiających faktyczną realizację tej funkcji. $Z$ tego też względu w literaturze prawa finansowego twierdzi się, że zastosowane w tym zakresie rozwiązania są zróżnicowane i wiążą się $\mathrm{z}$ koncepcją realizowanej $\mathrm{w}$ danym kraju, w danym czasie i wobec konkretnego społeczeństwa, polityki społecznej i ekonomicznej ${ }^{53}$. Wobec powyższego, za słuszne należy uznać twierdzenie, zgodnie z którym zakres redystrybucji podatkowej powinien być ograniczony do takich rozmiarów, które są niezbędne dla pokrycia uzasadnionych potrzeb publicznych ${ }^{54}$.

\footnotetext{
${ }^{46}$ GŁUChOwsKi, Polskie prawo podatkowe, s. 11.

${ }^{47}$ TENŻE, Funkcje podatków, s. 4.

${ }^{48}$ WerALSKI, Funkcje podatków, s. 56.

${ }^{49}$ WOLAŃSKI, System podatkowy w Polsce, s. 30.

${ }^{50}$ MAJCHRZYCKA-GuZOWSKA, Finanse i prawo finansowe, s. 79.

${ }^{51}$ MateCKA-ZiembińsKa, Podatek dochodowy, s. 14.

${ }^{52}$ Tamże.

${ }^{53}$ Tamże.

${ }^{54}$ GŁUchowski, Funkcje podatków, s. 4.
} 
Podatki pełnią również funkcję stymulacyjną (motywacyjną, interwencyjną, bodźcową). W doktrynie prawnopodatkowej podkreśla się, że funkcja ta ma uniwersalny charakter i występuje w państwach o różnych założeniach ustrojo$\mathrm{wych}^{55}$, a jej istota przejawia się w wywoływaniu lub zwiększaniu, przy pomocy konstrukcji podatkowych, zjawisk korzystnych dla społeczeństwa i gospodarki narodowej oraz hamowaniu lub eliminowaniu zjawisk, które jej szkodzą ${ }^{56}$. Powyższe nakłada na prawodawcę obowiązek takiego ukształtowania i wykorzystania instrumentów podatkowych, by sprzyjały one gospodarności działania, pobudzały do osiągania odpowiednich wyników ekonomicznych i finansowych, podejmowania działań przynoszących zyski oraz pożądane efekty społeczne, proeksportowe, itp. ${ }^{57}$ Praktyczna realizacja omawianej funkcji determinowana jest zatem wieloma subiektywnymi czynnikami, takimi m.in. jak wola ustawodawcy, nadany podatkowi kształt, czy zdolność trafnego przewidywania skutków ${ }^{58}$. Determinanty te wpływają zarówno na kształt systemu podatkowego, jak też na skuteczność wykorzystania go do celów stymulacyjnych. Praktycznym wyrazem realizacji analizowanej funkcji w sensie pozytywnym jest stosowanie systemu zwolnień i ulg podatkowych ${ }^{59}$. Szczególne znaczenie mają ulgi o charakterze inwestycyjnym (m.in. na zakup nowych technologii lub realizację celów badawczo-rozwojowych), stymulujące rozwój przedsiębiorców oraz zwiększające poziom ich konkurencyjności na globalnym rynku, a tym samym kształtujące wzrost gospodarczy, jak również oddziaływujące na podejmowane przez tych przedsiębiorców decyzje w zakresie struktury produkcji bądź zatrudniania nowych pracowników.

Negatywne znaczenie motywacyjnej funkcji podatków przejawia się natomiast w tworzeniu takich regulacji prawnych, których celem jest zniechęcenie podatników do podejmowania określonych przedsięwzięć, np. prowadzących do ograniczenia rozmiarów objętego opodatkowaniem rodzaju działalności. Jak wskazuje się w literaturze przedmiotu, posługiwanie się negatywnymi, zamiast pozytywnymi, instrumentami oddziaływania powinno mieć jedynie przejściowy charakter, zaś ich stosowanie związane jest zazwyczaj z występowaniem określonej sytuacji gospodarczej, np. ze złym stanem ekonomicznym, recesją czy inflacją występującą $\mathrm{w}$ danym kraju ${ }^{60}$. Jednocześnie zwraca się uwagę, że jeżeli podatki wykorzystywane są w tego rodzaju celach, to są traktowane jako instrument interwencji ${ }^{61}$.

\footnotetext{
${ }^{55}$ TeNŻE, Polskie prawo podatkowe, s. 11.

${ }^{56}$ WóJTOwICZ, Pojęcie i charakter podatku, s. 42; L. KUROwSKI, Wstęp do nauki prawa finansowego, Warszawa: PWN 1976, s. 11.

${ }^{57}$ N. GAJL, Teorie podatkowe w świecie, Warszawa: Wydawnictwo Naukowe PWN 1992, s. 131.

${ }^{58}$ TEGLER, Funkcje systemu podatkowego, s. 110.

${ }^{59}$ MAJCHRZYCKA-GuZOWSKA, Finanse i prawo finansowe, s. 79.

${ }^{60} \mathrm{GAJL}$, Teorie podatkowe w świecie, s. 133.

${ }^{61}$ NizioŁ, Prawne aspekty polityki podatkowej, s. 106.
} 
W związku z powyższym, postuluje się wydzielenie odrębnej funkcji podatków, obejmującej negatywne instrumenty wkomponowane w konstrukcje podatkowe o charakterze hamującym lub dyskryminującym, którą określa się mianem funkcji interwencyjnej lub funkcją negatywną opodatkowania ${ }^{62}$.

W doktrynie prawa finansowego wskazuje się ponadto, że motywacyjna funkcja podatków może mieć zarówno charakter ogólny, jak i selektywny ${ }^{63}$. Przy czym stymulacja ogólna może być realizowana poprzez ogólny poziom obciążenia podatkowego, okresowe zwolnienia od podatku, a także odpowiednią konstrukcję podstawy opodatkowania. Natomiast dla selektywnego motywowania wykorzystuje się ulgi oraz przedmiotowe zwolnienia podatkowe, dążąc do rozwoju określonych form działalności.

Stymulacyjna funkcja podatków może również dotyczyć sfery gospodarczej i pozagospodarczej ${ }^{64}$. W obrębie sfery gospodarczej obejmuje ona oddziaływanie na strukturę gospodarki narodowej, wpływ na kierunki i lokalizację działalności gospodarczej, dążność do zwiększania efektywności ekonomicznej oraz kształtowanie akumulacji i konsumpcji. Pozagospodarcza stymulacja podatkowa polega natomiast na stosowaniu sankcji lub ochrony wobec określonych warstw ludności, preferencji wobec działalności rzemieślniczej czy artystycznej ${ }^{65}$. Podatki mogą być również wykorzystywane do wywoływania określonych zmian w strukturze demograficznej społeczeństwa. Cel taki osiąga się m.in. stosując szeroko rozumiane różnicowanie wysokości obciążenia osób posiadających dzieci i bezdzietnych. Warto zwrócić uwagę, że zastosowane instrumenty o charakterze stymulacyjnym, pozwalające uwzględnić przy wymiarze podatku nie tylko wysokość uzyskanych dochodów, ale również indywidualną osobistą sytuację opodatkowanego, klasyfikowane są niekiedy w doktrynie do odrębnej funkcji określanej mianem społecznej lub socjalnej ${ }^{66}$. Jak podkreśla się w literaturze prawa finansowego, do realizacji zadań o charakterze społecznym predestynowane są podatki od dochodów osobistych, a to z uwagi na ich konstrukcję prawną nawiązującą wprost do dochodu jako miernika sytuacji materialnej podatników oraz umożliwiającą personalizację obciążeń podatkowych za pomocą różnego rodzaju zniżek i zwyżek podatkowych uwzględniających indywidualne położenie podatnika, jego

\footnotetext{
${ }^{62} \mathrm{GAJL}$, Teorie podatkowe w świecie, s. 133.

${ }^{63}$ SoKOŁOWSKI, Zarzadzanie przez podatki, s. 24.

${ }^{64}$ GŁUCHOwsKi, Funkcje podatków, s. 5.

${ }^{65}$ TENŻE, Polskie prawo podatkowe, s. 11.

${ }^{66}$ M. Pietrewicz, Polityka fiskalna, Warszawa: Poltext 1994, s. 58; R.A. Musgrave, P.B. MusGRAVE, Public Finance in Theory and Practice, New York: McGraw-Hill 1984, s. 368 n.
} 
wiek, zdolność do pracy, stan zdrowia, a także konieczność utrzymywania dzieci lub innych członków rodziny ${ }^{67}$.

W katalogu pozafiskalnych funkcji podatków wymienia się ponadto funkcję informacyjno-kontrolną (ewidencyjno-kontrolną, informacyjną, sygnalizacyjną). Jej istota polega na dostarczaniu władzy publicznej wiedzy o prawidłowościach lub nieprawidłowościach zachodzących w zjawiskach społecznych i gospodarczych. Posiadanie możliwie wiarygodnych informacji o różnych zjawiskach gospodarczych i społecznych stanowi bowiem warunek sine qua non podejmowania trafnych decyzji ${ }^{68}$. Jak twierdzi się w piśmiennictwie, podatki są swoistym barometrem stanu gospodarki ${ }^{69}$. Wysokość dochodów realizowanych przez budżet z podatków oraz ich wewnętrzna struktura są źródłem informacji w zakresie przebiegu procesów produkcji, podziału i wymiany ${ }^{70}$. Informacje te mają ogólny charakter, niemniej mogą być użyteczne i pomocne przy próbach określania i oceny zjawisk zachodzących $\mathrm{w}$ gospodarce, stanowiąc przesłankę podejmowania celowych, optymalnych decyzji przez organy władzy i administracji finansowej ${ }^{71}$. Pobór i wymiar podatków dokonywany głównie w formie ich samoobliczenia, dostarcza ponadto informacji na temat prawidłowości dokonanych przez podatników rozliczeń, w tym przede wszystkim ich legalności i rzetelności, i tym samym pozwala zapobiegać zjawiskom uznanym przez władzę publiczną za niepożądane oraz skutecznie je eliminować. Jak wskazuje się ponadto w literaturze przedmiotu, z omawianą funkcją związany jest także aspekt kompleksowego informowania społeczeństwa o obciążeniach podatkowych, słusznie twierdząc, że tylko wówczas może ono dokonywać kompetentnych wyborów między proponowanymi przez polityków programami ekonomicznymi ${ }^{72}$.

Omówione dotychczas, najczęściej wymieniane w literaturze przedmiotu pozafiskalne funkcje podatków nie stanowią wyczerpującego ich katalogu. W piśmiennictwie z zakresu prawa finansowego i ekonomii wskazuje się ponadto, że podatki pełnią funkcję alokacyjną i stabilizacyjną. Pierwsza polega na optymalnym podziale czynników produkcji (pracy i kapitału) między różnorodne zadania, umożliwiającym podniesienie poziomu społecznej zamożności ${ }^{73}$. Funkcja ta ma

\footnotetext{
${ }^{67}$ GAUdemet, Molinier, Finanse publiczne, s. 462-463.

${ }^{68}$ TEGLER, Funkcje systemu podatkowego, s. 111.

${ }^{69}$ KuZIŃSKa, Rola podatków pośrednich w Polsce, s. 87.

${ }^{70}$ SOKOŁOWSKI, Zarządzanie przez podatki, s. 25.

${ }^{71}$ E. ChOJNA-Duch, Podstawy finansów publicznych $i$ prawa finansowego, Warszawa: LexisNexis 2010, s. 41.

${ }^{72}$ KuZIŃSKA, Rola podatków pośrednich w Polsce, s. 88.

${ }^{73}$ Chojna-Duch, Podstawy finansów publicznych, s. 42.
} 
bowiem na celu zapobieganie ograniczenia dostępności do dóbr społecznych (np. służby zdrowia, oświaty, itp.) niektórych grup obywateli. U jej podstaw leży przekonanie o tym, że konieczna jest korekta pierwotnego podziału zasobów, który dokonuje się za pomocą mechanizmu rynkowego ${ }^{74}$. Wobec tego, poprzez odpowiednie konstrukcje podatkowe, władza publiczna może wpływać na kierunki alokacji czynników produkcji, a tym samym oddziaływać za ich pomocą na zmiany w strukturze wytworzonego dochodu narodowego. Funkcja stabilizacyjna wiąże się natomiast z wykorzystaniem podatków do oddziaływania na koniunkturę gospodarczą, przeciwdziałaniu jej wahaniom w celu ograniczenia inflacji, zapewnieniu zrównoważonego wzrostu gospodarczego, zrównoważonego bilansu płatniczego oraz pełnego zatrudnienia ${ }^{75}$. Konstrukcje podatkowe mają bowiem „wbudowaną" giętkość i dostosowują się do istniejącej koniunktury ${ }^{76}$. Jednocześnie podkreśla się, że przy rozpatrywaniu funkcji stabilizacyjnej ważną rolę odgrywa ogólny poziom podatków. Im jest on wyższy, tym większymi dochodami dysponuje państwo. To zaś pozwala zwiększać wydatki budżetowe, dzięki którym władza publiczna może aktywnie walczyć z bezrobociem, prowadzić prace interwencyjne i inwestycje publiczne oraz pobudzać popyt efektywny poprzez podnoszenie wysokości zasiłków dla bezrobotnych i innych transferów socjalnych wypłacanych z budżetu państwa ${ }^{77}$.

W piśmiennictwie prawnofinansowym wymienia się także inne funkcje, jakie mogą pełnić podatki, tj. funkcję konfliktową oraz koordynacyjną ${ }^{78}$. Należy jednak zwrócić uwagę, że funkcje te są często efektem zawężania zakresu celów realizowanych przez trzy funkcje podstawowe, tj. funkcję fiskalną, stymulacyjną lub informacyjną ${ }^{79}$. Wskazuje się ponadto, że podatki pełnią funkcję polityczną, jednakże nie jest ona zazwyczaj w literaturze przedmiotu wyodrębniana ${ }^{80}$.

\footnotetext{
${ }^{74}$ T. WŁUdyKa, M. SMAGA, Interwencja państwa w gospodarkę, [w:] Instytucje gospodarki rynkowej, red. T. Włudyka, M. Smaga, Warszawa: Wolters Kluwer 2012, s. 94.

${ }^{75}$ Chojna-Duch, Podstawy finansów publicznych, s. 42; NizıOŁ, Prawne aspekty polityki podatkowej, s. 107.

${ }^{76}$ KrajewsKa, Podatki w Unii Europejskiej, s. 60.

${ }^{77}$ Tamże.

${ }^{78}$ GaJl, Teorie podatkowe w świecie, s. 136.

${ }^{79}$ SoKOŁOWsKI, Zarzadzanie przez podatki, s. 26.

${ }^{80}$ Dolata, Podstawy wiedzy o podatkach, s. 55.
} 


\section{PODSUMOWANIE}

Z przeprowadzonych powyżej rozważań wynika, że podatki pełnią różnorodne funkcje, co często w praktyce prowadzi do konfliktu między nimi. Powyższa konstatacja implikuje konieczność określenia ich hierarchii, tj. uporządkowania funkcji, jakie pełnią podatki według ważności, przy jednoczesnym zapewnieniu wewnętrznej ich spójności ${ }^{81}$. Jedynie wówczas można zapewnić skuteczne oddziaływanie podatków, a tym samym realizację przypisanych im zadañ ${ }^{82}$. Urzeczywistnienie powyższego postulatu wymaga m.in. uwzględnienia specyficznej natury danej grupy podatków (dochodowe, majątkowe, przychodowe, etc.), ich konstrukcji oraz ich swoistych cech. I tak, np. należy mieć na uwadze, że we współczesnych demokratycznych państwach prawa podatki od dochodów osobistych nie powinny odgrywać pierwszoplanowego znaczenia fiskalnego. Ich konstrukcja prawna przyjmująca dochód za podstawę opodatkowania będący odzwierciedleniem sytuacji materialnej podatników oraz ich osobisty charakter umożliwiający personalizację obciążeń podatkowych za pomocą różnego rodzaju zniżek i zwyżek podatkowych uwzględniających indywidualną sytuację każdego podatnika, jego wiek, zdolność do pracy, stan zdrowia, a także konieczność utrzymania członków rodziny powodują, że są one predestynowane do realizacji zadań społecznych. Powyższe nie oznacza jednak, że cele fiskalne tego podatku nie mają znaczenia. Podatek dochodowy od osób fizycznych, tak jak każdy inny podatek, powinien również zapewniać władzy publicznej określonej wysokości dochody służące pokryciu wydatków publicznych. Mając powyższe na uwadze, zgodzić należy się ze stanowiskiem prezentowanym w doktrynie, że sprzeczności co do realizacji przez podatki poszczególnych funkcji pojawiają się wówczas, gdy podatki są niewłaściwie skonstruowane, zazwyczaj zbyt wysokie ${ }^{83}$. Dlatego też uznać należy, że warunkiem koniecznym dla prawidłowej konstrukcji i niezakłóconego funkcjonowania podatków jest zapewnienie swoistego kompromisu (właściwych relacji) w kwestii ich wykorzystania zarówno do celów fiskalnych, jak i pozafiskalnych ${ }^{84}$.

\footnotetext{
${ }^{81}$ Tamże, s. 58.

${ }^{82}$ Tamże.

${ }^{83}$ SoKOŁOWSKI, Zarzadzanie przez podatki, s. 25.

${ }^{84}$ Pomorska, Potrzeba wzmocnienie funkcji, s. 49-50.
} 


\section{BIBLIOGRAFIA}

BoLLAND Stefan: Wstęp do nauki finansów, Warszawa: Państwowe Wydawnictwo Ekonomiczne 1986. BORODO Andrzej: Polskie prawo finansowe. Zarys ogólny, Toruń: TNOiK 2003.

BRZEZIŃSKI Bogumił: Wstęp do nauki prawa podatkowego, Toruń: TNOiK 2001.

CHOJNA-Duch Elżbieta: Podstawy finansów publicznych i prawa finansowego, Warszawa: LexisNexis 2010

CZERWIŃSKA Elżbieta: Niektóre sporne problemy w dyskusji o finansach, [w:] Istota i funkcje finansów socjalistycznych. Zagadnienia dyskusyjne, red. B. Blass, Z. Fedorowicz, M. Orłowski, Warszawa: Państwowe Wydawnictwo Ekonomiczne 1965, s. 60-68.

DolatA Stanisław: Podstawy wiedzy o podatkach i polskim systemie podatkowym, Opole: Wydawnictwo Uniwersytetu Opolskiego 1999.

Dziemianowicz Ryta, PrZYGodzKa Renata: Funkcje podatków i ocena ich sprawności w rolnictwie, [w:] Kierunki reformy polskiego systemu podatkowego, red. A. Pomorska, Lublin: Wydawnictwo Uniwersytetu Marii Curie-Skłodowskiej 2003, s. 433-454.

ETEL Leonard: System podatkowy (zarys wykładu), Siedlce: Wyższa Szkoła Finansów i Zarządzania w Siedlcach 2002.

FEDOROwicz Zdzisław: Finanse w gospodarce socjalistycznej, Warszawa: Państwowe Wydawnictwo Ekonomiczne 1974.

GAJL Natalia: Teorie podatkowe w świecie, Warszawa: Wydawnictwo Naukowe PWN 1992.

Gaudemet Paul M., Molinier Joël: Finanse publiczne, Warszawa: Polskie Wydawnictwo Ekonomiczne 2000

GŁUCHOwSKI Jan: Funkcje podatków w gospodarce rynkowej, Przeglad Ustawodawstwa Gospodarczego 5 (1995), s. 1-5.

GŁUCHOWSKI Jan: Polskie prawo podatkowe, Warszawa: Wydawnictwo Naukowe PWN 1993.

GoMUŁOwICZ Andrzej: Funkcje systemu podatkowego [w:] Andrzej GoMUŁOwICZ, Dominik MĄCZYŃSKI, Podatki i prawo podatkowe, Warszawa: Wolters Kluwer 2016, s. 348-359.

GoMUŁOWICZ Andrzej: Mentalność i moralność podatkowa, Glosa 3 (1995), s. 1-3.

HARASIMOWICZ Jerzy: Finanse i prawo finansowe, Warszawa: Państwowe Wydawnictwo Ekonomiczne 1988

JAŚKIEWICZOWA Jadwiga: Prawo finansowe, Gdańsk: Wydawnictwo Uniwersytetu Gdańskiego 1988.

KOMAR Andrzej, ŁĄCZKOWSKI Wojciech: Finanse i prawo finansowe, Warszawa: PWN 1976.

KrajewsKa Anna: Podatki w Unii Europejskiej, Warszawa: Polskie Wydawnictwo Ekonomiczne 2012.

KUROWSKI Leon, WeRALSKI Marian: Prawo finansowe, Warszawa: PWN 1970.

KUROWSKI Leon: Wstęp do nauki prawa finansowego, Warszawa: PWN 1976.

KuZIŃSKA Hanna: Rola podatków pośrednich w Polsce, Warszawa: Wydawnictwo Wyższej Szkoły Przedsiębiorczości i Zarządzania 2002.

LAURÉ Maurice: Traité de politique fiscale, Paris: Presses Universitaires de France 1956.

MAJCHRZYCKA-GuzowsKa Alina: Finanse i prawo finansowe, Warszawa: Wydawnictwo Prawnicze PWN 1995.

MAŁECKA-ZIEMBiŃSKA Edyta: Efektywność fiskalna podatku dochodowego od osób fizycznych w Polsce, Poznań: Wydawnictwo UE w Poznaniu 2012.

MAŁECKA-ZIEMBiŃSKA Edyta: Podatek dochodowy jako regulator dochodów osób fizycznych w Polsce okresu transformacji ustrojowej, Poznań: Wydawnictwo Akademii Ekonomicznej w Poznaniu 2006.

Musgrave Richard A., Musgrave Peggy B.: Public Finance in Theory and Practice, New York: McGraw-Hill 1984.

NizIOŁ Krystyna: Prawne aspekty polityki podatkowej, Warszawa: Difin 2007. 
OfIARSKI Zbigniew: Ewolucja funkcji pozafiskalnej podatków w Polsce po roku 1990, [w:] Kierunki reformy polskiego systemu podatkowego, red. A. Pomorska, Lublin: Wydawnictwo Uniwersytetu Marii Curie-Skłodowskiej 2003, s. 101-114.

PARUSIŃSKI Lucjan: Krytyczna analiza podatków pośrednich w Polsce, Transformacja Gospodarki 56 (1995), s. 41-56.

PIETREwicz Mirosław: Polityka fiskalna, Warszawa: Poltext 1994.

POMORSKA Alicja: Potrzeba wzmocnienia funkcji redystrybucyjnej podatku dochodowego od osób fizycznych, [w:] Potrzeba i kierunki reformy podatków dochodowych w Polsce, red. A. Pomorska, Lublin: Wydawnictwo KUL 2016, s. 15-20.

RYBARSKI Roman: Nauka skarbowości, Warszawa: Zakład Drukarski F. Wyszyński i S-ka 1935.

SOKOŁOWSKI Jerzy: Zarządzanie przez podatki, Warszawa: PWN 1995.

Tegler Eugeniusz: Funkcje systemu podatkowego i ocena jego sprawności, Acta Universitatis Lodziensis, Folia Iuridica 54 (1992), s. 101-118.

WERALSKI Marian: Funkcje podatków a instrumenty podatkowe, [w:] System instytucji prawnofinansowych PRL, t. III: Instytucje budżetowe, red. M. Weralski, Warszawa: Ossolineum 1985, s. 53-87.

WERALSKI Marian: Zagadnienia systemu podatkowego w państwach socjalistycznych, Warszawa: Państwowe Wydawnictwo Ekonomiczne 1965.

WiCiAK Sławomir: Funkcja podatków w gospodarce rynkowej - analiza krytyczna, Zeszyty Naukowe Wydziału Zamiejscowego w Chorzowie Szkoty Wyższej Bankowej w Poznaniu 14 (2012), s. 59-70.

WiERZBicki Janusz, Wolniak Jerzy: Finanse w socjalizmie, Warszawa: Państwowe Wydawnictwo Ekonomiczne 1979.

WŁUDYKA Tadeusz, SMAGA Marcin: Interwencja państwa w gospodarkę, [w:] Instytucje gospodarki rynkowej, red. T. Włudyka, M. Smaga, Warszawa: Wolters Kluwer 2012, s. 94-99.

WOLAŃSKI Robert: System podatkowy w Polsce, Warszawa: Wolters Kluwer 2016.

WóJTowicz Wanda: Pojęcie i charakter podatku jako dochodu publicznego, [w:] Prawo podatkowe - część ogólna i szczegółowa, red. W. Wójtowicz, Bydgoszcz-Lublin: Oficyna Wydawnicza Branta 2005, s. 11-43.

\section{FUNKCJE PODATKÓW W DOKTRYNIE PRAWNOFINANSOWEJ ORAZ ICH ZNACZENIE DLA PRAKTYKI STANOWIENIA PRAWA PODATKOWEGO}

$$
\text { Streszczenie }
$$

Przedmiotem niniejszego artykułu jest charakterystyka funkcji, jakie w doktrynie prawnofinansowej realizują podatki oraz wskazanie ich znaczenia dla praktyki stanowienia prawa podatkowego. W pierwszej kolejności zwrócono uwagę na trudności dotyczące zdefiniowania pojęcia funkcji podatków oraz na brak ich jednolitego katalogu w doktrynie prawa finansowego. Następnie przedstawiona została fiskalna funkcja podatków, a w dalszej kolejności dokonano omówienia pozafiskalnych celów realizowanych przez te daniny publiczne, w głównej mierze scharakteryzowana została ich funkcja redystrybucyjna oraz stymulacyjna.

W niniejszym opracowaniu wskazano, że pomimo, iż podstawową funkcją podatków jest funkcja fiskalna, to nie wszystkie podatki realizują ją w takim samym stopniu. W szczególności pierwszoplanowego znaczenia fiskalnego nie powinny odgrywać podatki obciążające dochody osobiste obywateli, gdyż z uwagi na ich konstrukcję prawną są daninami publicznymi predestynowanymi do realizacji zadań o charakterze rozdzielczym i społecznym (socjalnym). Konstatacja ta stanowi, jak się wydaje, istotną wskazówkę dla praktyki stanowienia prawa podatkowego.

Słowa kluczowe: zadania podatków; nauka prawa finansowego; tworzenie prawa 


\section{FUNCTIONS OF TAXES IN THE LEGAL AND FINANCIAL DOCTRINE AND THEIR SIGNIFICANCE FOR THE PRACTICE OF TAX LAW MAKING}

\section{S u m m a r y}

The objective of this article is to describe the functions of taxes in the legal and financial doctrine and to indicate their significance for the practice of tax law making. First of all, attention was drawn to the difficulties related to the definition of the concept of tax functions and the lack of their uniform catalogue in the doctrine of financial law. Secondly, the fiscal function of taxes was discussed, and then the non-fiscal objectives pursued by these public levies were analysed, primarily their redistributive and stimulative functions were characterised.

This paper indicates that although the basic function of taxes is fiscal, not all taxes perform it to the same extent. In particular, the primary fiscal significance should not be played by taxes on personal income of citizens because - due to their legal structure - they are public levies predestined to perform separation and social tasks. This statement seems to be an important indication for the practice of tax law making.

Key words: tasks of taxes; financial law; law making 